\title{
The Behaviour of Azotobacter chroococcum in Oxygen- and Phosphate-limited Chemostat Culture
}

\author{
By H. LEES* AND J. R. POSTGATE \\ A.R.C. Unit of Nitrogen Fixation, \\ University of Sussex, Brighton, BNI $9 Q J$, Sussex
}

(Received 12 October 1972)

\begin{abstract}
SUMMARY
Oxygen-limited chemostat cultures of nitrogen-fixing Azotobacter chroococcum showed an inverse relation between biomass and dilution rate, accounted for largely by increased polysaccharide and polyhydroxybutyrate content. Abrupt increase in $\mathrm{pO}_{2}$ led to immediate increase in $\mathrm{CO}_{2}$ output followed later by increase in biomass and transition to $\mathrm{N}_{2}$ limitation; viability on $\mathrm{N}$-free and $\mathrm{NH}_{4}$-containing media remained at 80 to $100 \%$ during $\mathrm{O}_{2}$ stress. P-limited populations showed no respiratory reponse to $\mathrm{O}_{2}$ stress, viability dropped rapidly on $\mathrm{N}$-free medium though the populations were $100 \%$ viable on $\mathrm{NH}_{4}$ medium. These findings support the view that respiration in these bacteria has, in part, a protective function for nitrogenase.
\end{abstract}

\section{INTRODUCTION}

Continuous culture has been important in studies of azotobacters and has revealed unusual aspects of their physiology, notably $\mathrm{O}_{2}$-sensitivity when fixing $\mathrm{N}_{2}$, hypersensitivity in C-limited and P-limited conditions, $\mathrm{N}_{2}$-limited growth and 'switch-off' and 'switch-on' of nitrogenase in response to oxygen stress (see review by Hill, Drozd \& Postgate, 1972). Nutritional status so far studied with Azotobacter chroococcum include $\mathrm{NH}_{4}{ }^{+}-, \mathrm{N}_{2}-$, C-, $\mathrm{P}$-, and S-limitations. $\mathrm{O}_{2}$-limitation has not so far been examined although Andreeva \& Khmel (1970) recorded some properties of an $\mathrm{O}_{2}$-limited culture of $A$. vinelandii and Senior, Beech, Ritchie \& Dawes (1972) used chemostat culture as part of their study of the involvement of oxygen limitation in poly- $\beta$-hydroxybutyrate synthesis by $A$. beijerinckii.

This paper reports a study of $\mathrm{O}_{2}$-limited Azotobacter chroococcum with particular reference to the relation of respiration to $\mathrm{N}_{2}$-fixation and extends previous studies on $\mathrm{P}$ limited, $\mathrm{N}_{2}$-fixing cultures of $A$. chroococcum.

\section{METHODS}

Organisms and media. Stock cultures of Azotobacter chroococcum NCIB 8003 were maintained and used as described by Dalton \& Postgate (I969a, $b$ ) on 'mannitol $\mathrm{B}_{6}$ ' medium. Where P-limitation was investigated, the phosphate concentration was $0.9 \mathrm{mg} \mathrm{P} / 1$, one half the concentration used by Dalton \& Postgate (I $969 b$ ).

Viabilities. Viability was assessed by slide culture (Postgate, Crumpton \& Hunter, I96I) on mannitol $B_{6}$ medium solidified with agar. Viability was also assessed with solidified $B_{6}$ medium containing ammonium succinate $50 \mathrm{mg} \mathrm{NH}{ }_{4}^{+}-\mathrm{N} / 1\left(\mathrm{~B}_{6}-\mathrm{N}\right.$ medium).

* Visiting Professor from the Department of Microbiology, University of Manitoba, Winnipeg, R3 ${ }_{3}$ N2, Canada. 


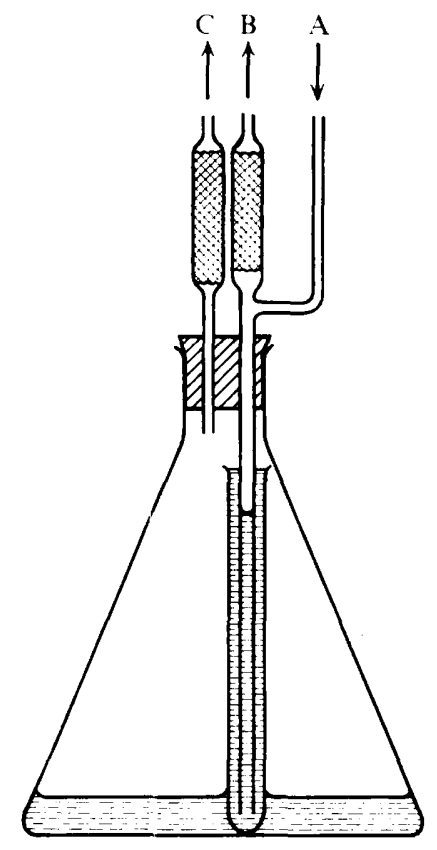

Fig. I. The 5-litre receiver vessel. A, The flow line from the continuous culture vessel; B, the gas line to the $\mathrm{CO}_{2}$-measuring percolator apparatus; $\mathrm{C}$, the air-release to the atmosphere.

Apparatus. The continuous culture apparatus (Baker, 1968) used had a working volume of $240 \mathrm{ml}$ and was in all respects operated as described by Dalton \& Postgate (1969a, b).

Analytical procedures. These were those used by Dalton \& Postgate (I969a,b) except that the DNA content of the bacteria was not regularly measured. Early measurements showed that the DNA content was about $2 \%$ of the bacterial dry wt under several conditions of culture. The contribution of DNA was thereafter disregarded in view of the fact that calculations of the $\mathrm{N}$ contributed by protein and RNA accounted for virtually all the total $\mathrm{N}$ in the cultures. One new analysis introduced was the measurement of the $\mathrm{CO}_{2^{-}}$ output of the cultures using a soil-percolator filled with glass beads in place of soil (Lees, 1949). A percolator needs a gas pressure slightly above one atmosphere if it is to operate properly. We therefore designed a simple effluent receiver vessel that trapped all $\mathrm{CO}_{2}$ originating from the culture at the time of measurement and that excluded any $\mathrm{CO}_{2}$ originating from the still-respiring effluent in the effluent vessel itself (Fig. I). The percolator was initially filled with $110 \mathrm{ml} \mathrm{O} \times \mathrm{M}-\mathrm{Ba}(\mathrm{OH})_{2}$ plus phenolphthalein indicator. The air-line to the continuous culture vessel was then disconnected from the culture vessel and connected directly to the percolator for $5 \mathrm{~min}$ to ensure even distribution of the $\mathrm{Ba}(\mathrm{OH})_{2}$ in the percolator. Two $5 \mathrm{ml}$ samples were then taken of the $\mathrm{Ba}(\mathrm{OH})_{2}$ and titrated against $0 . \mathrm{I} \mathrm{M}-\mathrm{HCl}$. The percolator, still connected in the same way, was run for $30 \mathrm{~min}$ and again two $5 \mathrm{ml}$ samples were titrated; this gave the ' $\mathrm{CO}_{2}$-blank' of the air supply. The culture vessel was then reconnected to the air supply and the percolator to the gas issuing from the culture (Fig. I). After $60 \mathrm{~min}$ a further two $5 \mathrm{ml}$ samples of the $\mathrm{Ba}(\mathrm{OH})_{2}$ were titrated against $\mathrm{O} \cdot \mathrm{I} \mathrm{M}-\mathrm{HCl}$. The difference between the second and third titrations, minus twice the blank shown by the difference between the first and second titrations, gave the $\mathrm{CO}_{2}$ output of the culture. Test runs showed that, when a flask containing a known amount of $\mathrm{KHCO}_{3}$ 


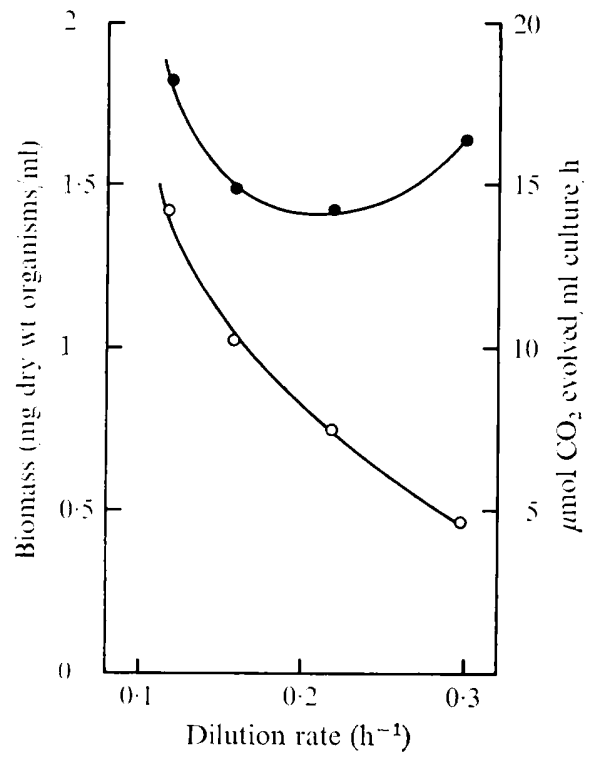

Fig. 2. The effect of dilution rate on $\mathrm{O}_{2}$-limited cultures of Azotobacter chroococcum. $\mathrm{O}$, Biomass;, $\mathrm{CO}_{2}$ output.

was inserted in the air-line and suddenly acidified by tipping in excess $\mathrm{H}_{2} \mathrm{SO}_{4}, 98 \%$ of the calculated $\mathrm{CO}_{2}$ output was trapped by the $\mathrm{Ba}(\mathrm{OH})_{2}$ within Io min. The 'blank' values, recorded over an 8 month period, showed that the $\mathrm{CO}_{2}$ content of the air supply was $0.03 \%$.

Experiments carried out under $\mathrm{O}_{2}$-limited and P-limited conditions were run for four days at each dilution rate and samples taken every day. All samples were analysed in duplicate. Each quoted analytical value is therefore the average of eight separate determinations. The number of replacement times used to establish a steady state before any samples were taken ranged from 7 to $2 \mathrm{I}$.

\section{RESULTS}

Continuous culture of $\mathrm{O}_{2}$-limited populations. A stirring rate was maintained so that, with air supplied to the cultures at $150 \mathrm{ml} / \mathrm{min}$, the $\mathrm{O}_{2}$ concentration within the culture approached the limit of detection (below Io $\mu \mathrm{M}$ ) with $\mathrm{B}_{6}$ medium. Evidence that the cultures were $\mathrm{O}_{2}$-limited under these conditions is given later. The dry weight of organisms fell steadily as the dilution rate $(D)$ was increased, while the $\mathrm{CO}_{2}$ output remained fairly constant (Fig. 2). No particular significance is attached to the dip in the $\mathrm{CO}_{2}$ curve; it is probably due to slight changes in the stirring rate (the line voltage in Britain at the time varied markedly) and in any case represents no more than a rise of $14 \%$ and a drop of I I $\%$ from an average value of I $6 \mu \mathrm{mol} \mathrm{CO} / 2 \mathrm{ml} \mathrm{culture} / \mathrm{h}$.

The composition of the organisms changed with dilution rate (Table I); we have no explanation for the abrupt rise in polysaccharide at $D=0.22 \mathrm{~h}^{-1}$ but it was real. The lowest polysaccharide contents ( 6 to $8 \%, \mathrm{w} / \mathrm{w}$ ) approach the minimum values quoted by Dalton \& Postgate ( $1969 b$ ) for chemostat populations of various nutritional status (4 to $5.4 \%, w / w)$, which may represent the minimum requirement of this strain for structural 


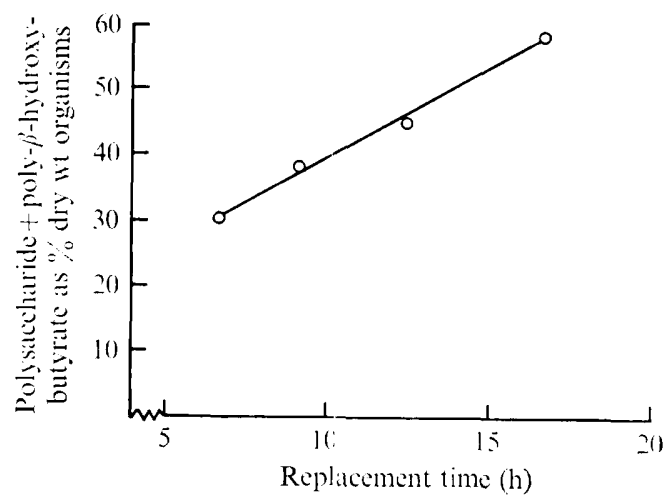

Fig. 3. The relation between replacement time and percentage of storage material (polysaccharide plus poly- $\beta$-hydroxybutyrate) in $\mathrm{O}_{2}$-limited chemostat cultures of Azotobacter chroococcum.

Table I. The macromolecular composition of nitrogen-fixing Azotobacter chroococcum in continuous culture

Values as \% dry weight of organisnıs; cultures at $30{ }^{\circ} \mathrm{C}$ in air except where stated.

$\begin{gathered}\text { Nutritional status } \\ \text { of population }\end{gathered}$
$\mathrm{O}_{2}$-limited

$\mathrm{N}_{2}$-limited $\dagger$

$\mathrm{PO}_{4}$-limited

$\mathrm{PO}_{4}$-limited, $\mathrm{O}_{2}$ poisoned

\begin{tabular}{|c|}
\hline $\begin{array}{c}\text { Dilution } \\
\text { rate } \\
\left(h^{-1}\right)\end{array}$ \\
\hline 0.12 \\
\hline 0.16 \\
\hline 0.22 \\
\hline 0.30 \\
\hline 0.25 \\
\hline 0.15 \\
\hline 0.15 \\
\hline
\end{tabular}

* Poly- $\beta$-hydroxybutyrate.

$\dagger$ Growing with 0.4 atm $\mathrm{O}_{2}$, see text.

$\begin{array}{ccc}\begin{array}{c}\text { Poly- } \\ \text { saccharide }\end{array} & \text { PHB* }^{*} & \text { RNA } \\ 6 & 51 & 9 \\ 9 & 34 & \text { I I } \\ 17 & 21 & 12 \\ 6 & 25 & 9 \\ 8 & 13 & \text { I4 } \\ 12 & 6 & \text { I4 } \\ 12 & 7 & \text { I4 }\end{array}$

rather than storage polysaccharide. The percentage of 'storage material' (polysaccharide plus poly- $\beta$-hydroxybutyrate) in the organisms was linearly related to the replacement time $(R)$ of the culture (Fig. 3). The residual mannitol in the culture rose from $3.5 \mathrm{mg} / \mathrm{ml}$ at $R=\mathrm{II} \cdot 8 \mathrm{~h}$ to $8.8 \mathrm{mg} / \mathrm{ml}$ at $R=6.7$ (the initial concentration was $10 \mathrm{mg} / \mathrm{ml}$ ).

Proof that cultures were genuinely $\mathrm{O}_{2}$-limited was provided by experiments in which the stirring rate of the culture was kept constant while the inflowing air was supplemented by extra $\mathrm{O}_{2}$ to give a final $p \mathrm{O}_{2}$ of 0.4 atm. Experiments at several dilution rates all gave similar results; typical was an experiment at $D=0.25$. An increase in $\mathrm{CO}_{2}$ output was detectable within the first hour after the $\mathrm{O}_{2}$ supply had been increased and after $24 \mathrm{~h}$ the $\mathrm{CO}_{2}$ output had risen from I $5 \mu \mathrm{mol} / \mathrm{ml}$ culture $/ \mathrm{h}$ to $25 \mu \mathrm{mol} / \mathrm{ml}$ culture $/ \mathrm{h}$. The dry wt of the culture had risen from 0.50 to $0.73 \mathrm{mg} / \mathrm{ml}$. The composition of the organisms changed slightly towards a lower percentage of 'storage material' (Table I) while the residual mannitol in the culture dropped from 8.8 to $7.8 \mathrm{mg} / \mathrm{ml}$. These values were maintained for the four days' duration of the experiment. The extra $\mathrm{O}_{2}$ supplied almost certainly changed the cultures from $\mathrm{O}_{2}$-limitation to $\mathrm{N}_{2}$-limitation. The composition of the bacteria supplied with extra $\mathrm{O}_{2}$ was virtually the same as the $\mathrm{N}_{2}$-limited bacteria described by Dalton \& 


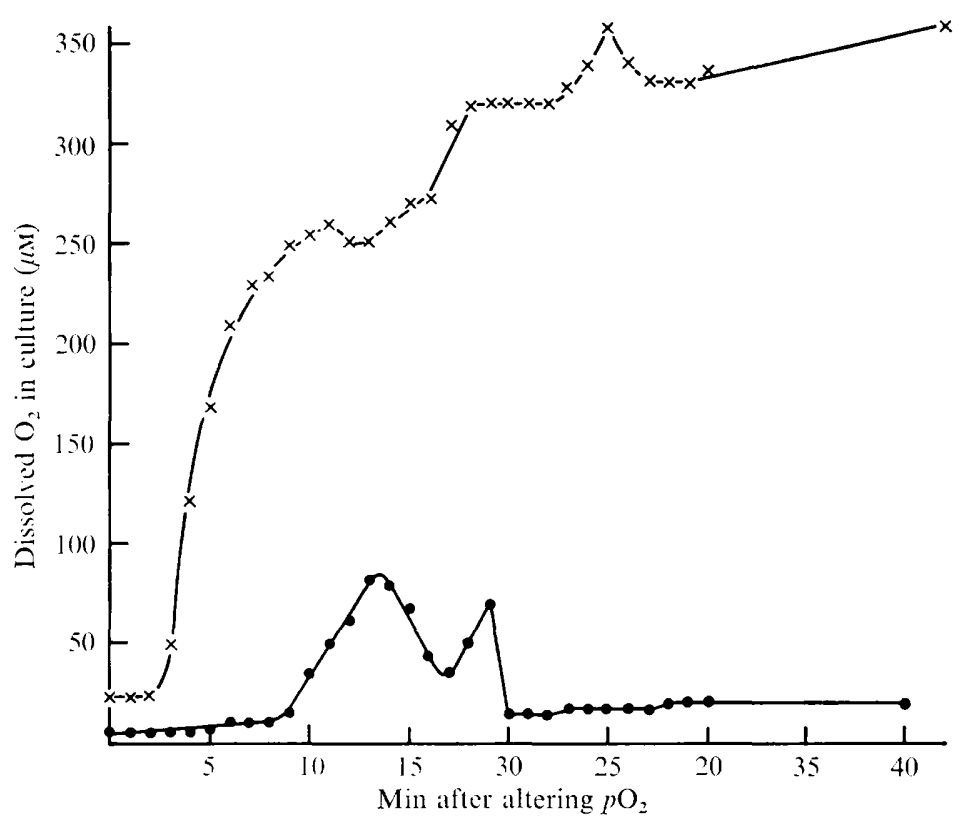

Fig. 4. The dissolved $\mathrm{O}_{2}$ concentration in chemostat cultures of Azotobacter chroococcum, grown in air in $\mathrm{B}_{6}$ media and supplied with extra $\mathrm{O}_{2}$ to 0.4 atm at start. tion; $\times, \mathrm{PO}_{4}$-limited population.

Postgate $(1969 b)$. Fig. 4 shows that, 10 min after the extra $\mathrm{O}_{2}$ was supplied to the culture, the dissolved $\mathrm{O}_{2}$ had risen from $7 \mu \mathrm{M}$ to $80 \mu \mathrm{M}$ but after $25 \mathrm{~min}$ it had stabilized at $20 \mu \mathrm{M}$ : oxygen consumption had evidently become rapidly adjusted to the increased oxygen supply.

Behaviour of phosphate-limited cultures. The response of P-limited cultures to raised $p \mathrm{O}_{2}$ was quite different. When exposed to 0.4 atm $\mathrm{O}_{2}$ for $4 \mathrm{~h}$, the composition of the organisms did not change (Table $\mathrm{I}$ ). That growth virtually ceased was shown by the fact that the turbidity, dry wt, and concentrations of protein, RNA, poly- $\beta$-hydroxybutyrate and polysaccharide all fell in accordance with washout as calculated from the dilution rate. Unlike the $\mathrm{O}_{2}$-limited cultures on medium $\mathrm{B}_{6}$, the P-limited cultures were quite incapable of restoring the $\mathrm{O}_{2}$ concentration within the culture to normal levels (Fig. 4); moreover, the $\mathrm{CO}_{2}$ output of the cultures dropped steadily as exposure to excess $\mathrm{O}_{2}$ continued. There was a small increase in residual mannitol concentration during the $4 \mathrm{~h}$.

Viability studies. $\mathrm{O}_{2}$-limited cultures had a viability of $75 \pm 5 \%$ on solidified $\mathrm{B}_{6}$ medium but $100 \%$ (no non-dividing cells were seen) on solidified $\mathrm{B}_{6}-\mathrm{N}$ medium. This suggests a slight physiological damage due to $\mathrm{O}_{2}$ deprivation. The viability of P-limited cultures before the cultures were challenged by excess $\mathrm{O}_{2}$ was about $100 \%$ on both $\mathrm{B}_{6}$ and $\mathrm{B}_{6}-\mathrm{N}$ media, but, after $4 \mathrm{~h}$ of exposure to excess $\mathrm{O}_{2}$, the viability on $\mathrm{B}_{6}$ medium was virtually zero while that on $\mathrm{B}_{6}-\mathrm{N}$ medium remained at $100 \%$, although the colonies were very small. These findings are consistent with Dalton \& Postgate's report (1969a) on the effect of $\mathrm{O}_{2}$ on P-limited cultures but those authors did not test viability on a solidified medium containing $\mathrm{NH}_{4}{ }^{+}$. 


\section{DISCUSSION}

It seems that, under $\mathrm{O}_{2}$-limited, $\mathrm{N}_{2}$-fixing conditions, Azotobacter chroococcum always synthesizes its essential protein and RNA at any dilution rate, but the percentage of 'storage material' (polysaccharide and poly- $\beta$-hydroxybutyrate) increases as the dilution rate is decreased, i.e. as the residence time of the bacteria in the culture vessel is increased (Fig. 3). This observation is consistent with the demonstration of Senior et al. (1972) that $\mathrm{O}_{2}$-limited $A$. beijerinckii synthesized much more poly- $\beta$-hydroxybutyrate than $\mathrm{C}$ - or $\mathrm{N}_{2}-$ limited populations. They suggested that the polymer served as an 'electron sink' as well as a storage polymer. When supplied with extra $\mathrm{O}_{2}$ and thus returned to a $\mathrm{N}_{2}$-limited state, A.chroococcum reverted to a composition almost exactly like that given by Dalton \& Postgate (I969a) for $\mathrm{N}_{2}$-limited $A$. chroococcum under the same culture conditions.

While $\mathrm{O}_{2}$-limited cultures subjected to excess $\mathrm{O}_{2}$ were easily able to increase their respiration so as to keep the level of dissolved $\mathrm{O}_{2}$ low, P-limited cultures were not. The composition of P-limited cultures did not change when excess $\mathrm{O}_{2}$ was supplied (Table I) but the bacteria simply ceased to grow and $\mathrm{CO}_{2}$ evolution fell. This suggests that the terminal-respiration system ceased to function properly, possibly because excess $\mathrm{O}_{2}$ drove all the transferable nucleotide $\mathrm{P}$ into ATP so that a normal ADP/ATP ratio could not be maintained. This would be in harmony with the results of Yates (I970) who presented evidence for continual respiratory control by the ADP/ATP ratio in Azotobacter chroococcum.

The viability tests showed that the 'lethal' effect of $\mathrm{O}_{2}$ stress on P-limited Azotobacter chroococcum reported by Dalton \& Postgate (I969a) is not real. The organisms remain viable after $\mathrm{O}_{2}$ stress if tested on a medium containing $\mathrm{NH}_{4}{ }^{+}$. It follows that $\mathrm{O}_{2}$ stress specifically affects nitrogenase or something closely associated with it. This is direct evidence for the view that respiration protects nitrogenase in $\mathrm{N}_{2}$-fixing organisms as suggested by Postgate and colleagues (see Hill et al. 1972).

We thank Miss Anne Bates for valuable technical assistance. One of us (H.L.) is indebted to the National Research Council of Canada for a Travel Grant that allowed his participation in this work.

\section{REFERENCES}

ANDREEVA, N. B. \& KHMEL, I. A. (1970). Kinetics of oxygen consumption by cells of Azotobacter vinelandii in batch and continuous cultivation. Mikrobiologiya 39, 28c-287.

BAKER, K. (1968). Low cost continuous culture apparatus. Laboratory Practice 17, 81 7-824.

Dalton, H. \& Postgate, J. R. (1969a). Effect of oxygen on growth of Azotobacter chroococcum in batch and continuous cultures. Journal of General Microbiology 54, 463-473.

Dalton, H. \& Postgate, J. R. (1969 b). Growth and physiology of Azotobacter chroococcum in continuous culture. Journal of General Microbiology 56, 307-319.

Hill, S., Drozd, J. W. \& Postgate, J. R. (IG72). Environmental effects on the growth of nitrogen-fixing bacteria. Journal of Applied Chemistry and Biotechnology 22, 54I-558.

LeEs, H. (I949). The soil percolation technique. Plant and Soil $\mathbf{~ r , ~} 22$ I-239.

Postgate, J. R., Crumpton, J. E. \& Hunter, J. R. (I96I). The measurement of bacterial viabilities by slide culture. Journal of General Microbiology 24, I 5-24.

Senior, P. J., Beech, G. A., Ritchie, G. A. F. \& Dawes, E. A. (I972). The role of oxygen limitation in the formation of poly- $\beta$-hydroxybutyrate during batch and continuous culture of Azotobacter beiierinckii. Biochemical Journal 128, I 193-1201.

Yates, M. R. (1970). Control of respiration and nitrogen fixation by oxygen and adenine nucleotides in $\mathrm{N}_{2}$-grown Azotobacter chroococcum. Journal of General Microbiology 6o, 393-401. 